DOI: https://doi.org/10.24127/ajpm.v10i4.4222

\title{
MATHEMATICS IN THE EMERGENCY PUBLIC ACTIVITY RESTRICTIONS (PPKM): HOW ABOUT SELF-CONFIDENCY OF THE STUDENTS?
}

\author{
Widya Ayu Pangestika', Adi Nurcahyo ${ }^{2}$ \\ ${ }^{1 *, 2}$ Universitas Muhammadiyah Surakarta \\ *Corresponding author. Ahmad Yani street, Pabelan, Kartasura, Surakarta 57162, Central Java, Indonesia \\ E-mail: $\quad$ a410180067@student.ums.ac.id ${ }^{1)}$ \\ an123@ums.ac.id ${ }^{2)}$
}

Received 14 September 2021; Received in revised form 17 November 2021; Accepted 18 December 2021

\begin{abstract}
This study aims to analyze student's self-confidence in learning mathematics during PPKM. This is descriptive qualitative research, where there are three students of PCGP organized by Universitas Muhammadiyah Surakarta. The auxiliary instruments consist of self-confidence questionnaires, interview guidelines, and field notes. Data collected by distribute questionnaires to research subjects, interviews with parents and teachers, and direct observations. Triangulation of sources and methods used to validate the obtained data. It showed that learning during PPKM did not have a significant effect on student's selfconfidence. The percentage of student's self-confidence in learning mathematics during PPKM was 85\%, which was quite good in accordance with the field conditions. Environment become vital role which was very necessary during online learning to assist students in learning.
\end{abstract}

Keywords: Mathematics; online learning; PPKM; self-confident.

\begin{abstract}
Abstrak
Penelitian ini bertujuan untuk menganalisis kepercayaan diri siswa dalam pembelajaran matematika di masa PPKM. Jenis penelitian yaitu penelitian deskriptif kualitatif dengan subjek penelitian sebanyak tiga siswa atau peserta Program Calon Guru Penggerak (PCGP) yang diselenggarakan oleh Universitas Muhammadiyah Surakarta. Instrumen bantu dalam penelitian ini berupa angket kepercayaan diri, pedoman wawancara, dan catatan lapangan. Pengumpulan data dilakukan dengan cara mendistribusikan angket kepada subjek penelitian, wawancara kepada orang tua dan guru, serta melakukan observasi secara langsung. Triangulasi sumber dan metode dijadikan cara untuk melihat keabsahan data yang diperoleh. hasil penelitian menunjukkan bahwa pembelajaran di masa PPKM tidak memiliki pengaruh yang signifikan terhadap kepercayaan diri siswa. Persentase kepercayaan diri siswa dalam pembelajaran matematika di masa PPKM sebesar $85 \%$ hasil yang cukup baik dan sesuai dengan keadaan lapangan. Peran lingkungan sekitar sangat diperlukan selama pembelajaran online untuk mendampingi peserta didik dalam belajar.
\end{abstract}

Keyword: Matematika; pembelajaran online; PPKM; Self-confidence.

This is an open access article under the Creative Commons Attribution 4.0 International License

\section{INTRODUCTION}

Apart from conspiracy theories, no one in this world expects a plague to cause a global pandemic. A virus that has the characteristics of being easy to spread, contagious, and quite deadly. All countries in the world have try to reduce the rate of the spread (Carbone et al., 2021). Some countries implement quarantine program, where people are restricted in their movements, strictly both their activities and mobility (Borkowski et al., 2021). while Indonesia, does not do a lockdown with 
various considerations (Azhari \& Fajri, 2021). Indonesia implements various policies that continue to change along with the number of confirmed patients. Each region has a different policy.

The current policy implemented by the regions in Indonesia is Pemberlakuan Pembatasan Kegiatan Masyarakat (PPKM) or popular called The Emergency Public Activity Restrictions. PPKM start to be use since the second wave of covid-19, which mentioned as delta variant. (Irawan et al., 2021). This second wave of attacks discouraged the government's intention to conduct limited direct learning that was planned to be carried out in June 2021. Learning carried out by online without any interaction between teachers and students directly as usual.

Online learning implementation during pandemic has been running since early of 2020 (Hendriyanto et al., 2021b). More than three semesters of students absent, they did not went to school. This was reasonable if this causes the changed of current learning paradigm from direct learning (face-toface) to online learning. (Hendriyanto et al., 2021a). However, the facts show that online learning was not relatively effective. Some obstacles was still encountered in various areas, such as the availability of mobile phones, weak internet network, lack of learning resources, lack of supervision, limitations of teachers in using technology, and others (Fitriana et al., 2021).

Online learning regulation should be implement to all subjects in school, including mathematics. It is one of the compulsory subjects at all levels of formal education in Indonesia. This is because mathematics is a source of other scientific developments (Zakiah \& Fajriadi, 2020). However, many people have the assumption that mathematics become a complicated and difficult subject to learn (Verschaffel et al., 2020). This assumption has been passed down from generation to generation, this makes students dislike or allergic to mathematics.

In other side, Indonesian infrastructure is not same every district and city. There are many different perception occurred through their familiarity level of mathematic development. This condition make selfconfidence differences. Students with good technology tend to be better on self-confidence. Teachers should consider using various manner in order to measure and to ensure high quality education for everyone.

The current K13 curriculum in Indonesia emphasizes that learning does not only focus on the cognitive domain, but also the affective and psychomotor aspects. (Ariawan et al., 2020). In mathematics, in the affective domain, there are several competencies that should be achieve in learning mathematics, such as having selfconfidence in solving mathematical problems. (Kaskens et al., 2020). It is argue that very important for students to have self-confidence in learning mathematic as a basic daily requirement in the real life.

Referring to the competencies that should be achieved it was normal if students need to have self-confidence in the learning process. In fact, there are still many students who feel afraid and not confident enough to learn mathematics (Szczygiel \& Pieronkiewicz, 2021). Weak selfconfidence will make students inactive in learning. Moreover, when students are required to learn independently. Today, online learning requires students to be more confident. 
DOI: https://doi.org/10.24127/ajpm.v10i4.4222

Lack of self-confidence will
hinder the student's learning development, because this kind of attitude causes students to be pessimistic and always feel doubtful when they want to express their opinions (Mumford \& Dikilitaş, 2020). Some students who are able to understand mathematics well are those who have high self-confidence. (Yaniawati et al., 2020).

Self-confidence competency must be embedded in every student, because self-confidence has an important role in student learning achievement. Student's self-confidence needs to be continuously trained, in order to useful both in learning and in life. The environment becomes a major factor in building student self-confidence (Kaur \& Prendergast, 2021), both the family, community, and school environment.

The limited interaction between people during PPKM certainly affects student's self-confidence. Students cannot meet directly with friends and teachers at school, even with their neighbors which nearer. This research would be important as a means to see student's self-confidence in learning during PPKM. As long, self-confidence become one of the competencies, which students in learning mathematics should need it. This initial research could be use as the basis data for determining appropriate actions to increase student's self-confidence.

Based on the important of selfconfidence for student, and the coming of online learning as pandemic covid-19 effect, everyone need to be fast to adapt. In other side, mathematic always become special major for student. This research try to analyze student's selfconfidence in learning mathematics during PPKM.

\section{METHOD}

The research was carried out refer to Program Calon Guru Penggerak (PCGP) or we can say the Activating Teacher Candidate Program, organized by the Muhammadiyah Surakarta University. This program focuses on designing fun learning in accordance with learning key point during pandemic by Kemendikbudristek (the ministry of education, research and technology Indonesia).

The research uses a qualitative descriptive approach, where the researcher as the main instrument. There are three students as research subjects. The students are teachers who participate PCGP. This amount of subject taken as there is only three teacher on mathematic education who is participating to PCGP. Observations carried out for four weeks, as well as interviews with teachers and parents. At the end of the study, the three subjects given a self-confidence questionnaire, which consist of 45 questions. Confidence questionnaires distributed at the end of the study. Consists of 45 questions covering aspects of 1) selfconfidence; 2) optimism; 3) objective; 4) be Responsibility; 5) rational and realistic (Yuli Amalia, M. Duskri, 2019). Every indicator has influence for student's self-confidence on learning mathematic.

The validity of the data based on the data obtained from each subject. The researcher compared the results of observations with a questionnaire, with the data validity technique used, namely triangulation of methods and sources. Data were analyzed using four stages; there were data collection, data reduction, data categorization, presentation and drawing conclusions. 


\section{RESULT AND DISCUSSION}

Teacher provided material and practice of mathematics learning through WhatsApp massager. It need one week to work on them. It's mention by $\mathrm{P} 1$ for parent $1, \mathrm{P} 2$ for parent 2, and P3 for parent 3, T1 for teacher 1. During the four weeks, two subjects found working on math assignments that were not in accordance with their lesson hours, while one subject did assignment when the task given. Feedback or question and answer offer directly through WhatsApp messenger. It known, if the interaction of students and teachers looked inactive in the forum, there was no discussion happens. Students tend to choose to ask their parents or siblings when they did not understand the material or questions. For any reason, it was fact if student have additional tutoring schedules with other outside teacher.

Table 1. Self-confidence percentage

\begin{tabular}{rlc}
\hline No & \multicolumn{1}{c}{ Item } & Percentage \\
\hline 1 & Self-confidence & $85 \%$ \\
2 & Optimism & $83 \%$ \\
3 & Objective & $84 \%$ \\
4 & be Responsibility & $85 \%$ \\
5 & Rational and Realistic & $87 \%$ \\
\hline \multicolumn{2}{c}{ Average } & $85 \%$ \\
\hline
\end{tabular}

Based on questioner data, it could be found that students has various condition. The results of the questionnaire showed $85 \%$ of students were included in the high category. This was satisfactory result, because almost all students believe could complete their homework as well as independently. It refer to Vidergor \& Ben-Amram (2020) research who said if students are given homework, then do it independently, it was the same as providing student's opportunity to get more learning experiences in order to help students developing themselves and thinking as well.

Detail data was confirmed by interviewed the respondent. "I can't explain mathematics, my profession as a housewife and cook for sales, can't help. So I prefer to call someone to tutor my child," said one of the student's parents (P1). It statement shows that, not all parents are able to supervise and to help their children to learn independently. Then, when confirmed about student's self-confidence, P2 explained, "I think my child is not embarrassed, it doesn't seem like it, but sometime, the questions answered by WhatsApp are unclear, my child feels more comfortable asking directly to the people around him. If he want to ask the teacher directly, he is not allowed to go to school". This explanation shows that students are confident enough to ask materials or teacher's assignment, which are difficult to others.

"Student scores are good during this pandemic. I do not know how to do it by their self or help by others. Clearly, they are orderly in collecting assignments and the results are quite good", T1 explain regarding the learning outcomes during the pandemic. Regarding student's self-confidence, the teacher explained if students often asked about material, they did not understand when they met.

Respondent has confidence enough to ask, also having good response in short talk. Sometimes, giving difficult question, while teachers hard to understand, but they have enough openness. The results of observations and interviews showed that students' self-confidence in mathematics subjects during PPKM was in the good category. This result was refer to Khair et al. (2021) research, which states that 
student's self-confidence on mathematic by online learning reveal to $86.7 \%$ with good level competencies. All the data showed triangulation method which refer to the use of multiple method on qualitative analysis. By this method could be found some phenomena if students has quality self-confidence even the suddenly coming of online era. They could adapt through what should be learn as well.

Ativetin (2021) explains that selfconfidence was a positive attitude of an individual that enables him to develop a positive assessment, both from their self and the environment or the several situation came. Lauster (1978) article found the aspects relate to selfconfidences followed:

1. The confidences of self-skills become positive attitude for someone, in order to be serious to do something needed.

2. Optimist is positive attitude, which possessed by someone who always has a good insight in dealing with everything about himself and his abilities.

3. Objective is the ability of a person to view the problem in accordance with the proper truth, not according to personal truth.

4. Responsibility is a person's willingness to bear everything that has become the consequence.

5. Rational and realistic is the ability to analyze a problem or something that reasonable could be accept by common sense, according to reality.

Self-confidence refers to a person's perceived ability to cope with something without relying on others and having a positive assessment of himself. The person will see himself as competent, independent, confident, moving forward, quite assertive, and has the qualities of ability.
Self-confidence is an attitude that allows individuals to have a positive but realistic view of themselves in every situation. These people, believing in their own abilities, control their lives, do what they want, plan and expect.

Irhamna et al. (2020) reveals that self-confidence is an attitude or feeling confident about someone's abilities. So that the person concerned is not too anxious in his actions, feels free to do what he likes, responsible for his actions, warm and polite enough in interacting with others, accepts and respects to others, and knows his own strengths and weaknesses to gain high achievement.

\section{CONCLUSIONS}

Based on the research findings and discussion above, it could be concluded, that learning during PPKM did not have a significant influence on student's confidence. Student's confidence in mathematics learning during PPKM amounted to $85 \%$, which are quite good in accordance with field conditions. Need of environment role to accompany learners during their study. Parent's inability to answer student's questions about material problems is not an obstacle in online learning. They could ask others to solve the problem. This shows that in online learning has a positive side that is increasing the independence and student's confidence.

This primary research only take on self-confidence student on learning mathematic, even though students got any problem in other subject. This research environment could be one example to use in other treatment. Which mean, everyone able to use difference variable for difference term and condition. There will be more selfconfidence analysis through difference area. 


\section{DAFTAR PUSTAKA}

Ariawan, I. P. W., Divayana, D. G. H., \& Suyasa, P. W. A. (2020). Initial design of blended learning for mathematics subject using the Kelase platform by adopting content of Tri Kaya Parisudha. Journal of Physics: Conference Series, $1470(1)$.

https://doi.org/10.1088/17426596/1470/1/012009

Ativetin, T. (2021). The Impact Of The Learning Organization On The Essential Behaviors Regarding Employee Retention During The Covid-19 Pandemic. $A B A C$ Journal, 41(3), 20-45.

Azhari, B., \& Fajri, I. (2021). Distance learning during the COVID-19 pandemic: School closure in Indonesia. International Journal of Mathematical Education in Science and Technology. https://doi.org/10.1080/0020739X. 2021.1875072

Borkowski, P., Jażdżewska-Gutta, M., \& Szmelter-Jarosz, A. (2021). Lockdowned: Everyday mobility changes in response to COVID-19. Journal of Transport Geography, 90(November 2020). https://doi.org/10.1016/j.jtrangeo.2 020.102906

Carbone, M., Lednicky, J., Xiao, S. Y., Venditti, M., \& Bucci, E. (2021). Coronavirus 2019 Infectious Disease Epidemic: Where We Are, What Can Be Done and Hope For. Journal of Thoracic Oncology, 16(4), 546-571. https://doi.org/10.1016/j.jtho.2020. 12.014

Dasalinda, D., Nopitasari, N., \& Fajri, N. (2021). Correlation of Self Confidence with Social Interaction Implications for Social Capability Development in Counseling
Guidance Services. Proceedings of the 1st Annual International Conference on Natural and Social Science Education (ICNSSE 2020), 547(Icnsse 2020), 282-288. https://doi.org/10.2991/assehr.k.21 0430.043

Fitriana, L., Hendriyanto, A., Sahara, S., \& Akbar, F. N. (2021). Digital Literacy: The Need for Technology-Based Learning Media in the Revolutionary Era 4.0 for Elementary School Children. International Journal of Progressive Sciences and Technologies (IJPSAT), 26(1), 194-200.

Hendriyanto, A., Kusmayadi, T. A., \& Fitriana, L. (2021a). Explain Point and Line Positioning Materials Using the Ethnomathematical Approach to Enhance Students' Geometric Thinking Skills. Psychology and Education, 58(5), 4199-4214.

Hendriyanto, A., Kusmayadi, T. A., \& Fitriana, L. (2021b). What are the type of learning media innovation needed to support distance learning? AKSIOMA: Jurnal Program Studi Pendidikan Matematika, 10(2), 1043-1052.

Irawan, M. Z., Belgiawan, P. F., Joewono, T. B., Bastarianto, F. F., Rizki, M., \& Ilahi, A. (2021). Exploring activity-travel behavior changes during the beginning of COVID-19 pandemic in Indonesia. Transportation, 0123456789. https://doi.org/10.1007/s11116021-10185-5

Irhamna, I., Amry, Z., \& Syahputra, H. (2020). Contribution of Mathematical Anxiety, Learning Motivation and Self-Confidence to Student's Mathematical Problem Solving. Budapest International 
DOI: https://doi.org/10.24127/ajpm.v10i4.4222

Research and Critics in Linguistics and Education (BirLE) Journal, 3(4), 1759-1772. https://doi.org/10.33258/birle.v3i4. 1343

Kaskens, J., Segers, E., Goei, S. L., van Luit, J. E. H., \& Verhoeven, L. (2020). Impact of Children's math self-concept, math self-efficacy, math anxiety, and teacher competencies on math development. Teaching and Teacher Education, 94, 103096. https://doi.org/10.1016/j.tate.2020. 103096

Kaur, T., \& Prendergast, M. (2021). Students' perceptions of mathematics writing and its impact on their enjoyment and selfconfidence. Teaching Mathematics and Its Applications: An International Journal of the IMA, $1-21$.

https://doi.org/10.1093/teamat/hrab 008

Khair, S. N., Soleh, H., \& Tangerang, U. M. (2021). Analisis dampak covid-19 terhadap kepercayaan diri siswa dalam pembelajaran matematika berbasis online. PENSA : Jurnal Pendidikan Dan Ilmu Sosial, 3(2), 311-321.

Lauster, P. (1978). The Personality Test (2nd Ed.) (2nd ed.). Pan Book, Ltd. Mumford, S., \& Dikilitaş, K. (2020). Pre-service language teachers reflection development through online interaction in a hybrid learning course. Computers and Education, 144(February 2019). https://doi.org/10.1016/j.compedu. 2019.103706

Szczygieł, M., \& Pieronkiewicz, B. (2021). Exploring the nature of math anxiety in young children: Intensity, prevalence, reasons. Mathematical Thinking and
Learning, $\quad 00(00), \quad 1-19$. https://doi.org/10.1080/10986065.2 021.1882363

Verschaffel, L., Schukajlow, S., Star, J., \& Van Dooren, W. (2020). Word problems in mathematics education: a survey. ZDM Mathematics Education, 52(1). https://doi.org/10.1007/s11858020-01130-4

Vidergor, H. E., \& Ben-Amram, P. (2020). Khan academy effectiveness: The case of math secondary students' perceptions. Computers and Education, 157(February), 103985. https://doi.org/10.1016/j.compedu. 2020.103985

Yaniawati, P., Kariadinata, R., Sari, N. M., Pramiarsih, E. E., \& Mariani, M. (2020). Integration of elearning for mathematics on resource-based learning: Increasing mathematical creative thinking and self-confidence. International Journal of Emerging Technologies in Learning, 15(6), 60-78. https://doi.org/10.3991/ijet.v15i06. 11915

Yuli Amalia, M. Duskri, A. A. (2019). Penerapan Model Eliciting Activities untuk Meningkatkan Kemampuan Berpikir Kreatif Matematis dan Self Confidence Siswa Sma. Jurnal Didaktik Matematika.

http://www.jurnal.unsyiah.ac.id/D M/article/view/2848

Zakiah, N. E., \& Fajriadi, D. (2020). Self regulated learning for social cognitive perspective in mathematics lessons. Journal of Physics: Conference Series, 1613(1). https://doi.org/10.1088/17426596/1613/1/012049 